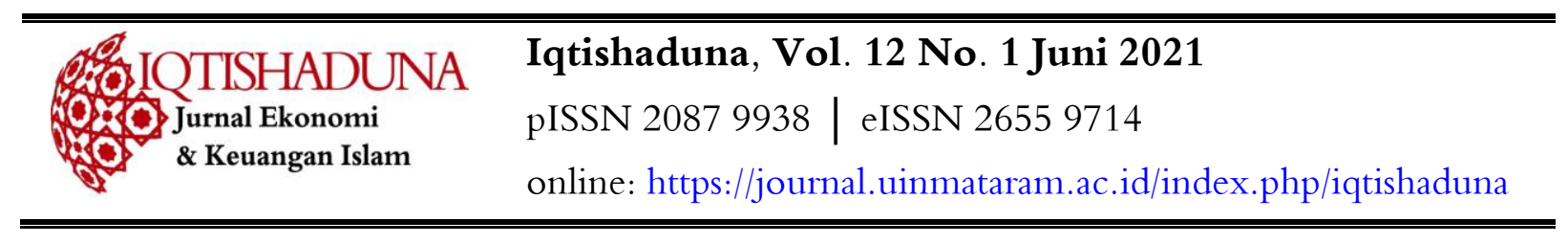

\title{
PENGARUH NPF, FDR DAN ROA TERHADAP PEMBIAYAAN BAGI HASIL PADA BANK UMUM SYARIAH
}

\author{
Dinda Naza Febriani ${ }^{1}$, Wirman ${ }^{2}$ \\ Universitas Singaperbangsa Karawang ${ }^{1,2}$ \\ dindanaza@gmail.com ${ }^{1}$ wirman@,feb.unsika.ac.id ${ }^{2}$
}

\begin{abstract}
This study aims to test the influence of NPF, FDR, and ROA on Profit Sharing Financing. The population of this research is Sharia Commercial Banks in Indonesia and the sample used is only 3 banks that fit the criteria. The data in this study was taken from the Quarterly Financial Statements of Sharia Commercial Banks for 3 periods, from 2017-2019. The results showed that NPF and ROA had a significant effect on Profit Sharing Financing while FDR did not affect Profit Sharing Financing. The predicting ability of the three variables to The Profit Sharing Financing in this study was $14.70 \%$ while the remaining $85.30 \%$ was influenced by other factors that were not included in the research model.
\end{abstract}

\section{Keywords : NPF, FDR, ROA, Profit Sharing Financing}

\section{PENDAHULUAN}

Menurut Undang-Undang RI Nomor 10 Tahun 1998 disebutkan bahwa bank adalah badan usaha yang menghimpun dana dari masyarakat dalam bentuk simpanan dan menyalurkan kepada masyarakat dalam bentuk kredit dan atau bentuk lainnya dalam rangka meningkatkan taraf hidup rakyat banyak.

Dalam Undang-Undang RI Nomor 10 Tahun 1998 tertulis pula bahwa bank umum melaksanakan kegiatan usaha secara konvensional dan atau berdasarkan prinsip syariah. Munculnya bank syariah sebagai pemain baru dalam dunia perbankan di Indonesia mendapat sambutan yang baik dari masyarakat, terutama masyarakat muslim. Bank syariah merupakan lembaga keuangan yang menggunakan prinsip syariah yaitu keadilan, keseimbangan dan kemaslahatan. Sebelum bank syariah berkembang, masyarakat hanya mengenal satu sistem perbankan yaitu sistem perbankan konvensional. Perbedaan mendasar antara bank konvensional dan bank syariah ini adalah adanya larangan bunga dalam bank syariah sebagaimana sistem bunga yang dianut oleh bank konvensional. Sehingga dalam menjalankan kegiatan operasinya, bank syariah menganut sistem bagi hasil. 
Febriani \& Wirman. NPF, FDR, ROA, dan Bagi Hasil Bank Umum Syariah

Eksistensi perbankan syariah di Indonesia saat ini semakin meningkat sejak adanya Undang-Undang Nomor 21 Tahun 2008 Tentang Perbankan Syariah yang memberikan landasan operasi yang lebih jelas bagi bank syariah. Perkembangan jumlah lembaga keuangan syariah yang terdiri dari Bank Umum Syariah (BUS), Unit Usaha Syariah (UUS) dan Bank Perkreditan Rakyat Syariah (BPRS) ditunjukkan dalam Tabel 1 berikut :

Tabel 1. Perkembangan Kelembagaan Perbankan Syariah

\begin{tabular}{ccccccccc}
\hline Kelompok & \multicolumn{8}{c}{ Tahun } \\
\cline { 2 - 7 } Bank & $\mathbf{2 0 0 4}$ & $\mathbf{2 0 0 6}$ & $\mathbf{2 0 0 8}$ & $\mathbf{2 0 1 1}$ & $\mathbf{2 0 1 4}$ & $\mathbf{2 0 1 7}$ & $\mathbf{2 0 1 8}$ & $\mathbf{2 0 1 9}$ \\
BUS & 3 & 3 & 5 & 11 & 12 & 13 & 14 & 14 \\
UUS & 15 & 20 & 27 & 23 & 22 & 21 & 20 & 20 \\
BPRS & 86 & 105 & 131 & 154 & 163 & 167 & 167 & 164 \\
\hline
\end{tabular}

Sumber : Dhian Dayinta (2012), Statistik Perbankan Syariah

Peningkatan eksistensi bank syariah di Indonesia juga didorong oleh tingginya minat masyarakat untuk menempatkan dananya di bank syariah dan telah berkembang menjadi sebuah tren. Dalam Laporan Perkembangan Perbankan Syariah (2009) disebutkan berkembangnya tren tersebut dikarenakan produk dana perbankan syariah memiliki daya tarik bagi deposan mengingat nisbah bagi hasil dan margin produk tersebut masih kompetitif dibanding bunga di bank konvensional.

Prinsip bagi hasil dalam perbankan syariah yang paling banyak dipakai adalah musyarakah dan mudharabah. Musyarakah adalah akad kerjasama antara dua pihak atau lebih untuk suatu usaha tertentu dimana masing-masing pihak memberikan kontribusi dana dengan kesepakatan bahwa keuntungan dan risiko akan ditanggung bersama sesuai dengan kesepakatan. Mudharabah berasal dari kata dharab, yang berarti berjalan atau memukul. Secara teknis, mudharabah adalah kerjasama usaha antara dua orang dimana pihak pertama (shohibul maal) menyediakan seluruh modal, sedangkan pihak lainnya menjadi pengelola. Keuntungan usaha dibagi menurut kesepakatan dalam kontrak, sedangkan apabila rugi ditanggung oleh pemilik modal selama kerugian itu bukan akibat kelalaian si pengelola. Seandainya kerugian itu diakibatkan karena kecurangan atau kelalaian pengelola, pengelola harus bertanggungjawab atas kerugian tersebut (Antonio, 2001).

Menurut Mufti Muhammad Taqi Usmani (2004) Murabahah bukan model pembiayaan, akad ini bentuk pelarian dari bunga sehingga hanya digunakan dalam proses transisi islamisasi bunga ke bagi hasil dan penggunaannya dibatasi dan jumlahnya tidak mendominasi di antara pembiayaan bagi hasil Mudharabah dan Musyarakah. Murabahah merupakan kontrak jual beli 
dimana bank menjual komoditi tertentu yang diminta oleh nasabah dengan harga baru yaitu harga asal komoditi ditambah margin keuntungan yang telah disepakati. Harga komoditi di pasaran cenderung naik dan harga baru yang diberikan oleh bank akan ikut naik, dengan begitu akad Murabahah mampu mendorong terjadinya inflasi.

Permasalahan yang mempengaruhi pembiayaan bagi hasil dipengaruhi oleh beberapa faktor internal dapat dilihat di dalam laporan keuangan masing-masing bank syariah tersebut.. Berikut beberapa faktor yang diduga mempengaruhi pembiayaan bagi hasil.

Non Performing Financing (NPF) adalah rasio untuk mengukur seberapa besar pembiayaan bermasalah yang ada pada bank syariah. Menurut penelitian yang dilakukan oleh Firaldi (2013) menyatakan bahwa NPF mempunyai pengaruh jangka pendek terhadap total pembiayaan. Sedangkan menurut Giannini (2013) menyatakan bahwa NPF tidak berpengaruh terhadap pembiayaan mudharabah. Kedua hasil penelitian tersebut saling bertentangan sehingga perlu dilakukan penelitian lebih lanjut.

Financing to Deposit Ratio (FDR) merupakan rasio yang digunakan untuk mengetahui tingkat likuiditas dari suatu bank, dengan rasio FDR yang tinggi menunjukan bahwa bank syariah tersebut kurang likuid. Menurut penelitian Giannini (2013) menyatakan bahwa rasio FDR berpengaruh negatif terhadap pembiayaan bagi hasil Mudharabah. Sedangkan penelitian yang dilakukan oleh Darmayanti, dkk (2013) menunjukan pertentangan dimana rasio FDR pengaruh positif signifikan terhadap pembiayaan berbasis bagi hasil perbankan syariah. Sehingga perlu dilakukan penelitian lebih lanjut.

Return on Assets (ROA) merupakan rasio yang menunjukkan hasil atas jumlah aktiva yang digunakan dalam perusahaan (Kasmir, 2014). Menurut penelitian yang dilakukan oleh Fitriyanti, Azib dan Nurdin (2014) menyatakan bahwa ROA tidak ada pengaruh signifikan terhadap pembiayaan bagi hasil. Sedangkan penelitian yang dilakukan oleh Gumilarty dan Indriani (2016) menyatakan bahwa ROA berpengaruh signifikan terhadap pembiayaan bagi hasil.

Dengan adanya research gap antara penelitian sebelumnya maka perlu dilakukan penelitian lanjutan pengaruh NPF, FDR dan ROA terhadap Pembiayaan Bagi Hasil.

Perbedaan penelitian ini dengan penelitian sebelumnya adalah penelitian ini menggunakan sampel tiga bank umum syariah yang akan melakukan penggabungan (merger) yaitu Bank Syariah Mandiri, BNI Syariah dan BRI Syariah. Agar bisa menjadi perbandingan peneliti selanjutnya bagaimana pengaruh NPF, FDR dan ROA terhadap Pembiayaan Bagi Hasil sebelum dan sesudah tiga bank tersebut merger. 
Febriani \& Wirman. NPF, FDR, ROA, dan Bagi Hasil Bank Umum Syariah

\section{STUDI LITERATUR}

\section{Pengaruh NPF terhadap Pembiayaan Bagi Hasil}

Non Performing Financing (NPF) menggambarkan besarnya risiko kredit yang dihadapi bank. Semakin kecil NPF, maka semakin kecil pula resiko kredit yang ditanggung pihak bank. (Riyadi, 2006).

Ketika rasio NPF tinggi menunjukan bahwa bank tersebut kurang mampu menjaga dan mengatur jalannya pembiayaan karena banyaknya pembiayaan yang bermasalah. Dari situ lah diprediksi bahwa NPF mempunyai pengaruh negatif terhadap penyaluran pembiayaan bagi hasil bank syariah periode selanjutnya.

Hal ini sesuai dengan teori yang menyatakan bahwa semakin tinggi rasio NPF makaakan menyebabkan nilai pembiayaan bagi hasil menjadi turun (Prastanto, 2013).

H1 : Non Performing Financing (NPF) berpengaruh terhadap Pembiayaan Bagi Hasil.

\section{Pengaruh FDR terhadap Pembiayaan Bagi Hasil}

Rasio Financing to Deposit Ratio itu sendiri adalah perbandingan antara pembiayaan yang diberikan oleh bank dengan dana pihak ketiga yang berhasil dikerahkan oleh bank (Muhammad, 2005), seberapa besar pembiayaan yang diberikan kepada masyarakat atau nasabah bank harus mampu mengimbanginya dengan segera memenuhi kebutuhan akan penarikan kembali dana sewaktu-waktu oleh deposan.

Semakin tinggi nilai FDR menunjukkan semakin besar pembiayaan bagi hasil yang telah disalurkan ke nasabah. Apabila FDR semakin tinggi maka kesempatan bank untuk memperoleh keuntungan juga semakin tinggi sehingga bank akan lebih tertarik untuk menyalurkan pembiayaan bagi hasil di tahun berikutnya.

Hal ini sesuai dengan penelitian yang dilakukan oleh Prastanto (2013) yang menyatakan bahwa FDR berpengaruh positif terhadap pembiayaan murabahah yang disalurkan oleh bank.

H2 : Financing to Deposit Ratio (FDR) berpengaruh terhadap Pembiayaan Bagi Hasil.

\section{Pengaruh ROA terhadap Pembiayaan Bagi Hasil}

Pendapatan yang diperoleh oleh suatu bank merupakan suatu hal yang penting bagi aktivitas operasional perbankan, termasuk dalam melakukan kegiatan pembiayaan karena besarnya pendapatan yang diperoleh menjadi sebuah acuan bagi perbankan untuk meningkatkann pembiayaan, sebab semakin meningkatnya laba maka semakin meningkatnya sejumlah aset yang dapat disalurkan melalui pembiayaan (Nugraha, 2014). 
Kemampuan perbankan untuk memperoleh laba atas sejumlah aset yang dimiliki olen bank dapat diukur dengan rasio ROA. ROA merupakan indikator kemampuan perbankan untuk memperoleh laba atas sejumlan aset yang dimiliki oleh bank (Pandia, 2012). Oleh karena iu, Jika rasio ROA meningkat mengartikan bahwa aktiva bank telah digunakan dengan optimal untuk memperoleh laba, sehingga dengan laba yang besar maka pinak bank dapat melakukan penawaran pembiayaan yang lebih banyak termasuk pemblayaan bagi hasil. Hal ini sesuai dengam penelitian yang dilakukan oleh Sune dkk (2014).

H3 : Return on Assets (ROA) berpengaruh terhadap Pembiayaan Bagi Hasil.

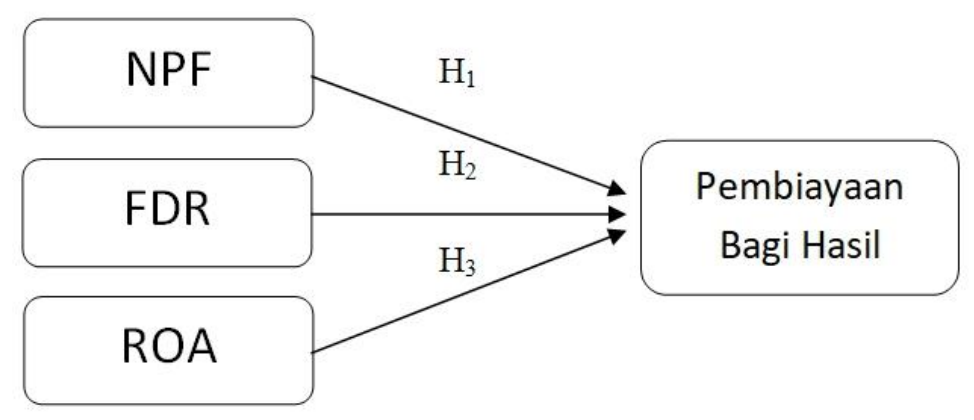

\section{Gambar 1. Kerangka Pemikiran}

\section{METODOLOGI}

Data penelitian merupakan data time series selama kurun waktu tahun 2017 sampai dengan tahun 2019, sehingga diperoleh jumlah observasi (titik pengambilan sebanyak 36 yang didapat dari 3 X 4 X 3 (perkalian antara jumlah sampel sebanyak tiga bank umum syariah dengan periode triwulan dalam pengamatan). Populasi yang digunakan dalam penelitian ini adalah seluruh Bank Umum Syariah di Indonesia. Pemilihan sampel dalam penelitian ini menggunakan kriteria yang telah ditetapkan yaitu: Bank Umum Syariah yang memiliki laporan keuangan dan mempublikasikan laporan triwulan periode 2017-2019 dan bank yang akan melakukan penggabungan (merger). maka Bank Umum Syariah yang memenuhi syarat yaitu Bank Syariah Mandiri, BNI Syariah dan BRI Syariah. Data sekunder dalam penelitian ini bersumber dari publikasi Laporan Keuangan Triwulan Bank Umum Syariah yaitu Bank Syariah Mandiri, BNI Syariah dan BRI Syariah yaitu data Non Performing Financing (NPF), Financing to Deposit Ratio (FDR), Return on Assets (ROA) dan Pembiayaan Bagi Hasil yang diperoleh dari website www.mandirisyariah.co.id, www.bnisyariah.co.id dan www.brisyariah.co.id. 
Febriani \& Wirman. NPF, FDR, ROA, dan Bagi Hasil Bank Umum Syariah

\section{HASIL DAN PEMBAHASAN}

Dari Tabel 2, dapat kita ketahui bahwa nilai rata-rata NPF sebesar 4,0375, nilai tertingi 6,73 dan nilai terendah 2,44 sedangkan standar deviasi NPF sebesar 1,11678. Untuk rasio FDR mempunyai nilai rata-rata 78,6508, nilai terendah FDR 68,70 dan nilai tertinggi 90,40, sedangkan standar deviasi FDR 4,40927. Untuk Rasio ROA mempunyai nilai rata-rata 1,0442, nilai terendah ROA 0,31, nilai tertinggi 1,97 dan nilai standar deviasi ROA 0,49771. Untuk Pembiayaan Bagi Hasil mempunyai nilai rata-rata Rp 12.825.225.330.000, nilai terendah Pembiayaan Bagi Hasil Rp 4.142.806.000.000 dan nilai tertinggi Rp 28.500.574.000.000, sedangkan standar deviasi Pembiayaan Bagi Hasil Rp 7.775.041.789.000.

Tabel 2. Hasil Statistik Deskriptif

\begin{tabular}{lrrrrr}
\hline & N & Min & \multicolumn{1}{c}{ Max } & \multicolumn{1}{c}{ Mean } & \multicolumn{1}{c}{ Std. Deviation } \\
\hline NPF & 36 & 2,44 & 6,73 & 4,0375 & 1,11678 \\
FDR & 36 & 68,70 & 90,40 & 78,6508 & 4,40927 \\
ROA & 36 &, 31 & 1,97 & 1,0442 &, 49771 \\
Pembiayaan & 36 & 4142806 & 28500574 & 12825225,33 & 7775041,789 \\
Bagi Hasil & & & & & \\
Valid N & 36 & & & & \\
(listwise) & & & & & \\
\hline \multicolumn{2}{l}{ Sumber: Data diolah peneliti, 2021 } & & & &
\end{tabular}

Berdasarkan Tabel 3, pengujian terhadap normalitas data dengan menggunakan uji Kolmogorov Smirnov menunjukkan bahwa data variabel NPF, FDR, ROA dan Pembiayaan Bagi Hasil mempunyai nilai signifikansi sebesar 0,153. Dimana hasilnya menunjukkan tingkat signifikansi diatas 0,05 . Hal ini berarti data yang ada pada semua variabel yang digunakan berdistribusi normal.

Tabel 3. Hasil Uji Kolmogorov-Smirnov (K-S)

\begin{tabular}{llr}
\hline & & Unstandardized Residual \\
\hline N & & 36 \\
Normal Parameters & Mean &, 0000000 \\
Most Extreme Differences & Std. Deviation &, 127 \\
& Absolute &, 127 \\
& Positive &,- 094 \\
Test Statistic & Negative &, 127 \\
Asymp. Sig. (2-tailed) & &, $153^{\mathrm{c}}$ \\
\hline Sumber: Data diolah peneliti, 2021 & &
\end{tabular}


Dari uji scatterplot di bawah, dapat diartikan bahwa titik-titik tidak membentuk suatu pola tertentu yang jelas serta titik menyebar di atas dan di bawah sumbu 0 (nol) pada sumbu Y maka tidak terjadi heteroskedastisitas pada penelitian ini.

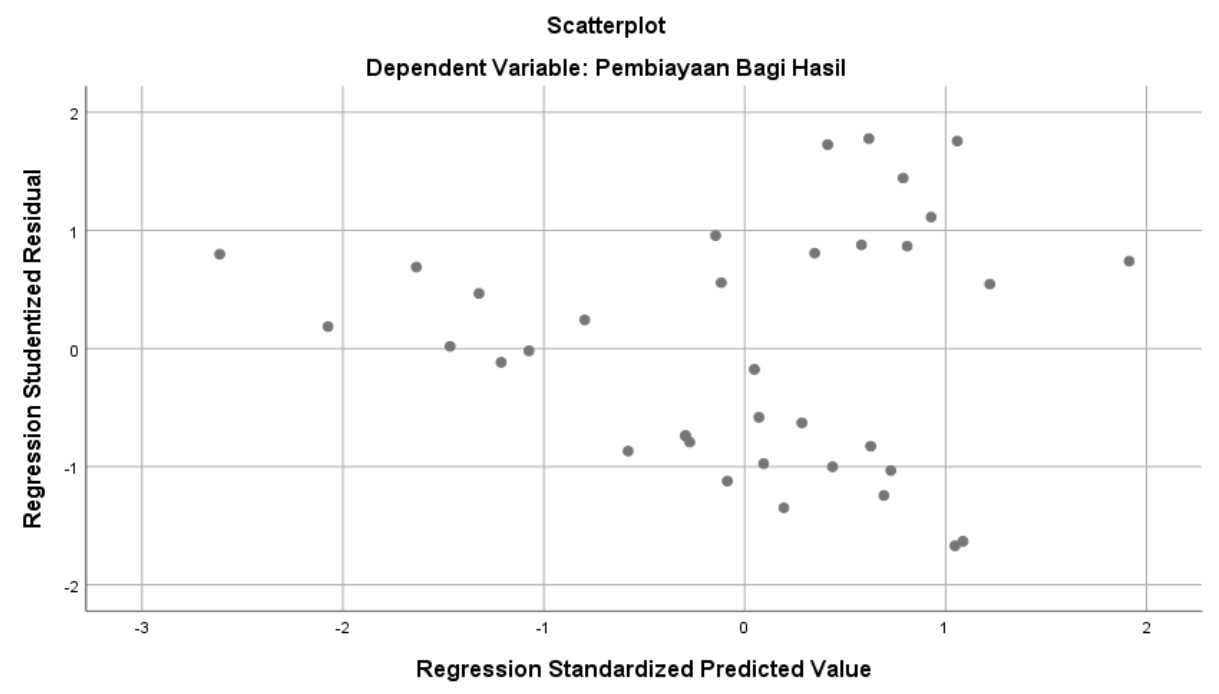

Gambar 2. Hasil Uji Heteroskedastisitas dengan Scatterplot

Sumber: Data diolah peneliti, 2021

Hasil pengujian tolerance menunjukkan tidak ada variabel bebas yang memiliki nilai tolerance kurang dari 0,1. Hasil perhitungan VIF juga menunjukkan bahwa tidak ada satu variabel bebas yang memiliki nilai VIF lebih dari 10. Oleh karena itu, dapat disimpulkan bahwa tidak ada multikolinearitas antara variabel dalam penelitian ini.

Tabel 5. Hasil Uji Multikolonieritas

\begin{tabular}{|c|c|c|c|}
\hline & \multirow{2}{*}{ Model } & \multicolumn{2}{|c|}{ Collinearity Statistics } \\
\hline & & Tolerance & VIF \\
\hline \multirow[t]{3}{*}{1} & NPF & ,262 & 3,822 \\
\hline & FDR & ,902 & 1,109 \\
\hline & ROA & 276 & 3,619 \\
\hline
\end{tabular}

Sumber: Data diolah peneliti, 2021

Hasil uji autokolerasi menggunakan Durbin Watson menunjukkan bahwa nilai DW pada model regresi sebesar 1,945, nilai ini akan dibandingkan dengan tabel DW yang menggunakan signifikansi 0,05, jumlah sampel $36(\mathrm{n}=36)$ dan jumlah variabel independen $3(\mathrm{k}=3)$. Berdasarkan tabel DW tersebut didapatkan nilai $\mathrm{dL}=1,2953 \mathrm{dan} \mathrm{dU}=1,6539$. Besarnya nilai $4-\mathrm{dU}=4-$ $1,6539=2,3461$. Karena $\mathrm{dU}<\mathrm{DW}<4-\mathrm{dU}=1,6539<1,945<2,3461$. Maka dapat 
Febriani \& Wirman. NPF, FDR, ROA, dan Bagi Hasil Bank Umum Syariah

disimpulkan berarti tidak terdapat autokorelasi. Dengan demikian maka analisis ini dapat dilanjutkan.

Tabel 6. Hasil Uji Autokorelasi dengan Durbin Watson

\begin{tabular}{lccccc}
\hline Model & R & R Square & $\begin{array}{c}\text { Adjusted R } \\
\text { Square }\end{array}$ & $\begin{array}{c}\text { Std. Error of the } \\
\text { Estimate }\end{array}$ & $\begin{array}{c}\text { Durbin- } \\
\text { Watson }\end{array}$ \\
\hline 1 &, $485^{\text {a }}$ &, 235 &, 161 &, 31130 & 1,945 \\
\hline Sumber: Data diolah peneliti, 2021 & & & & &
\end{tabular}

Berdasarkan tabel di bawah dapat diketahui bahwa F hitung sebesar 3,007 dengan nilai probabilitas sebesar 0,045. Nilai probabilitas kurang dari 0,05. Hal ini menunjukkan bahwa model penelitian yang digunakan baik / fit dan secara simultan variabel independen merupakan penjelas yang signifikan terhadap variabel dependen.

Tabel 7. Hasil Uji F

\begin{tabular}{|c|c|c|c|c|c|c|}
\hline & del & Sum of Squares & df & Mean Square & $\mathrm{F}$ & Sig. \\
\hline \multirow[t]{3}{*}{1} & Regression & 465315596727794,800 & 3 & 155105198909264,940 & 3,007 &, $045^{b}$ \\
\hline & Residual & 1650479021852284,800 & 32 & 51577469432883,900 & & \\
\hline & Total & 2115794618580079,500 & 35 & & & \\
\hline
\end{tabular}

Sumber: Data diolah peneliti, 2021

Berdasarkan Tabel 8, maka dapat dijelaskan sebagai berikut :

a. Pengaruh NPF terhadap Pembiayaan Bagi Hasil

Dari tabel diatas hasil uji NPF memiliki nilai signifikansi kurang dari 0,05 yaitu 0,005 maka Hipotesis 1 diterima. Hal ini menunjukkan bahwa secara parsial NPF berpengaruh signifikan terhadap Pembiayaan Bagi Hasil pada Bank Umum Syariah.

b. Pengaruh FDR terhadap Pembiayaan Bagi Hasil

Dari tabel diatas hasil uji FDR memiliki nilai signifikansi lebih dari 0,05 yaitu 0,377 maka Hipotesis 2 ditolak. Hal ini menunjukkan bahwa secara parsial FDR tidak berpengaruh signifikan terhadap Pembiayaan Bagi Hasil pada Bank Umum Syariah.

c. Pengaruh ROA terhadap Pembiayaan Bagi Hasil

Dari tabel diatas hasil uji ROA memiliki nilai signifikansi kurang dari 0,05 yaitu 0,024 maka Hipotesis 3 diterima. Hal ini menunjukkan bahwa secara parsial ROA berpengaruh signifikan terhadap Pembiayaan Bagi Hasil pada Bank Umum Syariah. 
Tabel 8. Uji T

\begin{tabular}{llrrrr}
\hline Model & \multicolumn{2}{c}{ Unstandardized Coefficients } & $\begin{array}{c}\text { Standardized } \\
\text { Coefficients }\end{array}$ & $\mathrm{t}$ & Sig. \\
\hline \multirow{2}{*}{1} & \multicolumn{1}{c}{$\mathrm{B}$} & \multicolumn{1}{c}{ Std. Error } & Beta & & \\
Constant & 70346589,661 & 28961972,452 & & -429 &, 021 \\
NPF & $-6348965,177$ & 2125174,025 &,- 912 & $-2,988$ &, 005 \\
FDR & $-259602,362$ & 289959,954 &,- 147 &,- 895 &, 377 \\
ROA & $-10984333,875$ & 4639883,445 &,- 703 & $-2,367$ &, 024 \\
\hline
\end{tabular}

Sumber: Data diolah peneliti, 2021

Nilai koefisien determinasi adalah sebesar 0,147 hal ini berarti bahwa variabel Pembiayaan Bagi Hasil dapat dijelaskan oleh NPF (X1), FDR (X2) dan ROA (X3) sebesar $14,70 \%$. Sedangkan sisanya $85,30 \%$ dijelaskan oleh variabel-variabel lain yang tidak terdapat dalam model regresi.

Tabel 9. Koefisien Determinasi

\begin{tabular}{lrrrr}
\hline Model & R & R Square & Adjusted R Square & $\begin{array}{c}\text { Std. Error of the } \\
\text { Estimate }\end{array}$ \\
\hline 1 &, $469^{\mathrm{a}}$ &, 220 &, 147 & 7181745,570 \\
\hline Sumber: Data diolah peneliti, 2021 & & &
\end{tabular}

\section{SIMPULAN}

Hasil pengujian variabel NPF terhadap Pembiayaan Bagi Hasil pada Bank Umum Syariah periode tahun 2017 sampai dengan tahun 2019 membuktikan bahwa ada pengaruh signifikan terhadap Pembiayaan Bagi Hasil. Hal ini dibuktikan dengan hasil uji t dengan signifikansi sebesar 0,018 nilai signifikansi kurang dari 0,05. Hasil penelitian ini menunjukkan bahwa secara parsial NPF mempengaruhi pihak bank dalam meningkatkan Pembiayaan Bagi Hasil.

Hasil pengujian variabel FDR terhadap Pembiayaan Bagi Hasil pada Bank Umum Syariah periode tahun 2017 sampai dengan tahun 2019 membuktikan bahwa tidak ada pengaruh signifikan terhadap Pembiayaan Bagi Hasil. Hal ini dibuktikan dengan hasil uji t dengan signifikansi sebesar 0,377 nilai signifikansi lebih dari 0,05. Hasil penelitian ini menunjukkan bahwa secara parsial FDR tidak mempengaruhi pihak bank dalam meningkatkan Pembiayaan Bagi Hasil.

Hasil pengujian variabel ROA terhadap Pembiayaan Bagi Hasil pada Bank Umum Syariah periode tahun 2017 sampai dengan tahun 2019 membuktikan bahwa ada pengaruh positif signifikan terhadap Pembiayaan Bagi Hasil. Hal ini dibuktikan dengan hasil uji t dengan signifikansi sebesar 0,024 nilai signifikansi kurang dari 0,05. Hasil penelitian ini menunjukkan 
Febriani \& Wirman. NPF, FDR, ROA, dan Bagi Hasil Bank Umum Syariah

bahwa secara parsial ROA mempengaruhi pihak bank dalam meningkatkan Pembiayaan Bagi Hasil.

Untuk penelitian selanjutnya dapat menambahkan variabel independen dengan Dana Pihak Ketiga (DPK), Tingkat Bagi Hasil, Capital Adequacy Ratio (CAR), Biaya Operasional dan Pendapatan Operasional (BOPO), Penempatan Dana pada SBIS, dan faktor internal dan faktor eksternal bank lainnya, dan juga Bank Umum Syariah yang lain. Serta menggunakan metode dan alat uji yang lebih lengkap dan akurat sehingga diperoleh kesimpulan yang lebih valid.

\section{REFERENSI}

Antonio. M.S. 2001. Bank Syariah Dari Teori ke Praktek. Penerbit Gema Insani Press. Jakarta.

Darmayanti, dkk. 2013. Faktor yang mempengaruhi Volume pembiayaan Berbasis Bagi Hasil Pada Perbankan Syariah di Indonesia.

Dhian. Dayinta Pratiwi. 2012. Pengaruh CAR, BOPO, NPF dan FDR Terhadap Return On Asset (ROA) Bank Umum Syariah (Studi Kasus Pada Bank Umum Syariah Di Indonesia Tahun 2005 -2010). Skripsi. Universitas Diponegoro Semarang. Semarang.

Firaldi. Mufqi. 2013. Analisis Pengaruh Jumlah Dana Pihak Ketiga (DPK), Non Performing Financing (NPF) dan Tingkat Inflasi terhadap Total Pembiayaan yang Diberikan Oleh Bank Pembiayaan Rakyar Syariah (BPRS) di Indonesia (Periode Januari 2007-Oktober 2012). Jakarta: UIN Syarif Hidayatullah.

Fitriyanti. Citra, Azib dan Nurdin. 2014. Pengaruh Dana Pihak Ketiga, Return on Assets (ROA), Capital Adequacy Ratio (CAR), Biaya Operasional dan Pendapatan Operasional (BOPO) Terhadap Pembiayaan Bagi Hasil (Studi Kasus pada Seluruh Bank Syariah di Indonesia Periode Tahun 2010-2013). Prosising Peneltian Sivitas Akademika. Unisba (Sosial dan Humaniora).

Giannini. Nur Gilang. 2013. Faktor yang mempengaruhi pembiayaan mudharabah pada bank umum syariah di Indonesia. Accounting Analysis Journal, AAJ 2 (1), 2013. Program Studi Akuntansi Fakultas Ekonomi Universitas Negeri Semarang.

Gumilarty. Gittrys Ratu Mashita dan Indriani, Astiwi. 2016. Analisis Pengaruh DPK, NPF, ROA, Penempatan Dana pada SBIS, dan Tingkat Bagi Hasil terhadap Pembiayaan Bagi Hasil (Studi Pada Bank Umum Syariah di Indonesia Periode Tahun 2010-2014). Diponegoro Journal of Management.

Kasmir. 2014. Analisis Laporan Keuangan. Jakarta: Raja Grafindo Persada

Muhammad. 2005. Manajemen Perbankan. Yogyakarta: UPP AMPYKPN. 
Nugraha. Siti. 2014. Pengaruh ROA, NPF, FDR, BOPO dan Tingkat Bagi Hasil terhadap Pembiayaan Mudharabah. Skripsi. Dipublikasikan. Jakarta : Universitas Islam Negeri Syarif Hidayatullah.

Pandia.Frianto. 2012. Manajemen Dana dan Kesehatan Bank. Jakarta: Rineka Cipta.

Prastanto. 2013. "Faktor Yang Mmpengaruhi Pembiayaan Murabahah Pada Bank Umum Syariah Di Indonesia”. Accounting Analysis Journal, 1(3).

Riyadi, Slamet. 2006. Banking Assets and Liability Management. Jakarta : Fakultas Ekonomi Universitas Indonesia.

Sune, Nur Fitria, Imran Rosman Hambali, dan La Ode Rasuli. 2014. Pengaruh ROA, CAR, dan Tingkat Bagi Hasil terhadap Pembiayaan Mudharabah pada PT. Bank Muamalat Indonesia Tbk.“Jurnal Akuntansi Universitas Negeri Gorontalo”.

Usmani, Muhammad Taqi (2004). "An Introduction to Islamic Finance” Karachi : Maktaba Ma'arifatul Quran.

www.bnisyariah.co.id (Di akses tanggal 10 Januari 2021)

www.brisyariah.co.id (Di akses tanggal 10 Januari 2021)

www.mandirisyariah.co.id (Di akses tanggal 10 Januari 2021) 